\title{
RESEARCH PAPER \\ Determination of suitable zones for apitourism using multi-criteria evaluation in geographic information systems: a case study in the O’Higgins Region, Chile ${ }^{1}$
}

\author{
Gabriel Pantoja, Miguel Gómez, Claudio Contreras, Lissette Grimau, and \\ Gloria Montenegro \\ Pontificia Universidad Católica de Chile, Facultad de Agronomía e Ingeniería Forestal, Departamento de \\ Ciencias Vegetales. Avenida Vicuña Mackenna 4860, Macul, Santiago, Chile.
}

\begin{abstract}
G. Pantoja, M. Gómez, C. Contreras, L. Grimau, and G. Montenegro. 2017. Determination of suitable zones for apitourism using multi-criteria evaluation in geographic information systems: a case study in the O'Higgins Region, Chile. Cien. Inv. Agr. 44(2): 139-153. Beekeeping, which involves honey production and pollination of agricultural crops, has become a significant production activity. Linking beekeeping with ecotourism brings greater value to the beekeeping sector, thereby attracting the development of apitourism. Multi-criteria decision analysis is a set of techniques developed through Geographic Information Systems (GIS) focused on spatial decision making, which can be used to link beekeeping and tourism for the development of priority sites for shared activity. This work is based on the definition and weighting of factors used for evaluation of apitourism suitability in Chile, considering the opinion of beekeepers and professionals associated with the sector. The result is a map of apitouristic suitability that includes vegetation, tourism, precipitation, temperature, roads, rivers and genetically modified crops (GM crops), as well as three restrictions: soil use, highways and wild areas protected by the state. The model allowed the localization of priority sites for resources and efforts pertaining to the development of apitourism.
\end{abstract}

Key words: Beekeeping, geographic information systems (GIS), Land-use suitability analysis, melliferous plant, multi-criteria decision analysis (MCDA), tourism.

\section{Introduction}

In many developing countries, beekeeping plays an important role in overcoming poverty in rural areas due to the additional income provided

Received November 29, 2016. Accepted July 07, 2017 Corresponding author: gmonten@uc.cl by selling beehive products. Honey is the main natural product from Apis mellifera $\mathrm{L}$. , which is derived from flowers (floral honey), secretions of living parts of plants, or excretions from sucking insects (honeydew honey) that are found, collected, gathered, transformed and stored by bees in the combs of the hive (Montenegro, 2012). In addition to honey production, bees play a very significant 
role in the pollination of different plant species. Estimates have suggested that bees pollinate approximately $90 \%$ of the flowering plants needing pollination, and approximately $75 \%$ of these plants serving as food. Namely, many intrinsically associated cultivated plants or species would not exist without bees; thus, a world without bees would be rather different than the world we know (Basualdo and Bedascarrasbure, 2003).

Among the countries exporting honey, Chile currently ranks 20 th, and as in previous years, honey remains as the main primary farming product with export value, surpassing cattle and ovine meat. In fact, a study by Glaría (2013) indicates that some of the most profitable non-timber forest products are currently derived from beekeeping. Additionally, it is predicted that the consumption of these products will increase. Clear evidence that Chilean beekeeping is growing is that the "Comisión Nacional Apícola" met for the first time in May of 2014, where public-private work sub-commissions were formed. "Sustainability and territory" was one of the main concepts of the commission.

Based on the growing demand for honeys with geographic designation and special features, preserving melliferous plant species and their respective pollinating agents will become essential. Therefore, more effort should be placed on the preservation of shrublands ("matorral") and sclerophyllous forest, as well as the honey bees supporting their pollination. In fact, the plant communities of central Chile have high ecological value due to the high levels of endemicity; it is regarded as a priority conservation area around the world (Myers et al., 2000). In central Chile, sustainable beekeeping has enabled the recovery of matorral and sclerophyllous forest (Glaría, 2013).

According to Cárcamo (2010), honey production is uneven in the O'Higgins Region and concentrated in micro-enterprises, which appears to provide valuable and sustainable work, but there are sanitary, commercialization and technologi- cal transference breaches, among other factors. This leads to the lack of a common long-term view among producers and a subsequent gap for improving competitiveness. There are approximately 1,000 beekeepers in the region associated with large, medium and small producers, and they are arranged through the 3 provinces.

Linking beekeeping to other industries such as tourism adds higher value to the sector, as there exists a current tendency toward ecotourism and agrotourism. Apitourism consists of guided visits to apiaries where the tourist will wear a beekeeper suit, learn about beekeeping and apitherapy, and taste hive-derived-products. The opportunity for new experiences surrounding specific natural and cultural realities in a region is increasingly fostering tourist trips. Many countries have documented apitouristic activities. For example, Slovenia is a pioneer in the implementation of apiroutes, in which ideal ecosystems favor the activity, strengthening sustainability and environmentally friendly projects (Šivic, 2013).

Beekeepers, government and private agencies, and academic representatives must agree on the location of beehives in the territory, and each group will indicate their preferences for ideal apitouristic sites. However, the decision is complex, and differences in opinions will typically need to be confronted; for example, GM crops and the application of neonicotinoid pesticides represents a symbol for how difficult it can be make for different actors to reach an agreement.

Multi-criteria decision analysis (MCDA) is a group of techniques supporting decision making and providing a framework consisting of multiple evaluation opinions and criteria, followed by selection of an appropriate course of action. Malczewski (2006) studied the increased use of this technique and in synergy with supplementary use of geographic information systems (GIS) in recent decades. This technique has been applied to a wide range of applications, such as assessment 
of the ecological capacity in multiple territory use (Babaie-Kafaky et al., 2009), assessment of territory suitability for beekeeping (Amiri and Shariff, 2012), waste disposal (Leão et al., 2004), environmental planning (Bojórquez-Tapia et al., 2001) and forest restoration (Orsi et al., 2010), among others.

The main purpose of this study was to evaluate the apitouristic suitability of the O'Higgins Region using GIS and MCDA techniques. The study presents an empirical method for land suitability analysis involving acting groups and experts in decision making. The result is a map of apitouristic suitability that was validated by statistical analysis and honey samples from apiaries in the area whose botanical origin was previously analyzed.

\section{Materials and methods}

\section{Study area}

The study area (Figure 1) corresponded to the Region of Libertador General Bernardo O'Higgins in central Chile $\left(16.365 \mathrm{~km}^{2}\right.$ in surface and spatial contrasts generating elements such as relief), and it represents an adequate area for a study of this kind. This region presents a Mediterranean-type climate with winter rains, mild temperatures and a long dry season in the summer (Di Castri and Hajek, 1976). The climate is colder in high mountains mainly due to elevation. Regarding relief, the territory consists of four major units: well-developed coastal plains, the Coastal Mountain Range, the Longitudinal Central Valley and the Andean Mountain Range (Sánchez and Carvacho, 2006).

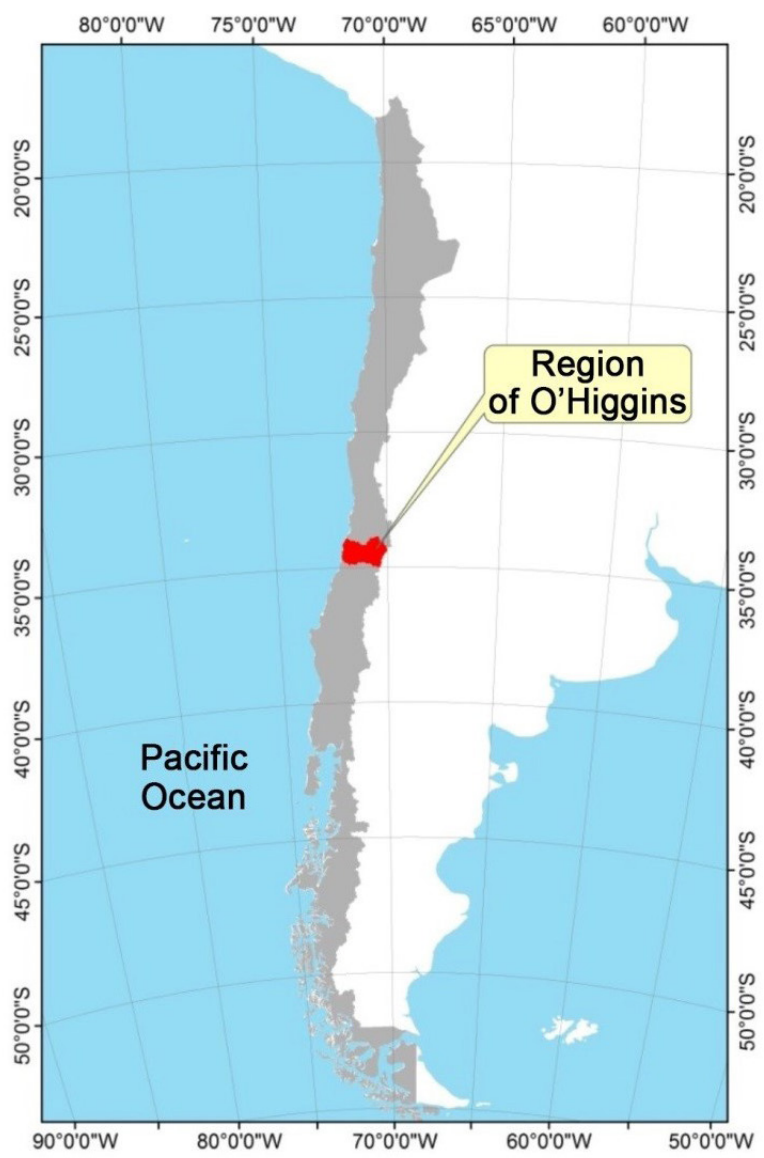

Figure 1. Study area: Region of Libertador General Bernardo O’Higgins. 


\section{Conceptual model}

The methodology reflects the process of decision making by Simon (1960) involving tools from (GIS) and (MCDA) in a conceptual model adapted from Estoque and Murayama (2010) (Figure 2). The conceptual model basically consists of three stages: i) database creation and management, ii) spatial and multi-criteria analysis, and iii) statistical validation. Database creation and management includes a collection of primary and secondary data and preparation of thematic layers for analysis. The spatial and multi-criteria analysis involves evaluation, prioritization and weight assignment to criteria: factors and restrictions and includes an analytic hierarchy process (AHP). Finally, the model includes a validation component providing the opportunity for truthfulness determination of the suitability map, and a final suitability map is generated.

\section{Database creation and management}

Data from different sources were used to determine adequate sites for apitourism in the O'Higgins Region (Table 1). Data were either freely available from the internet or available by request under Transparency Laws, except for the survey and the analysis of honey samples. This represents an advantage, as the study can be easily duplicated or elaborated at a different scale (for example, at the domestic level), or used as an example for similar studies. The spatial data were aligned and manipulated in the program ArcGIS version 10 (C1999-2010 ESRI Inc.).

For the multi-criteria decision analysis, the criteria and preferences were combined, and because the data are in different units of measurement (e.g., distance in meters, precipitation in $\mathrm{mm}$, temperature in ${ }^{\circ} \mathrm{C}$ ), each layer was necessarily transformed to intercomparable units (Malczewski 2006). Therefore, a normalization process was carried out considering the value function, converting the score of original criteria in degrees of convenience according to the type of criterion.

Land use and the presence of native melliferous species were considered to elaborate the vegetation factor; tourism included an index of tourism priority; then, all the polygons were simply divided by the highest value. The areas of influence of genetically modified crops determined by "Servi-

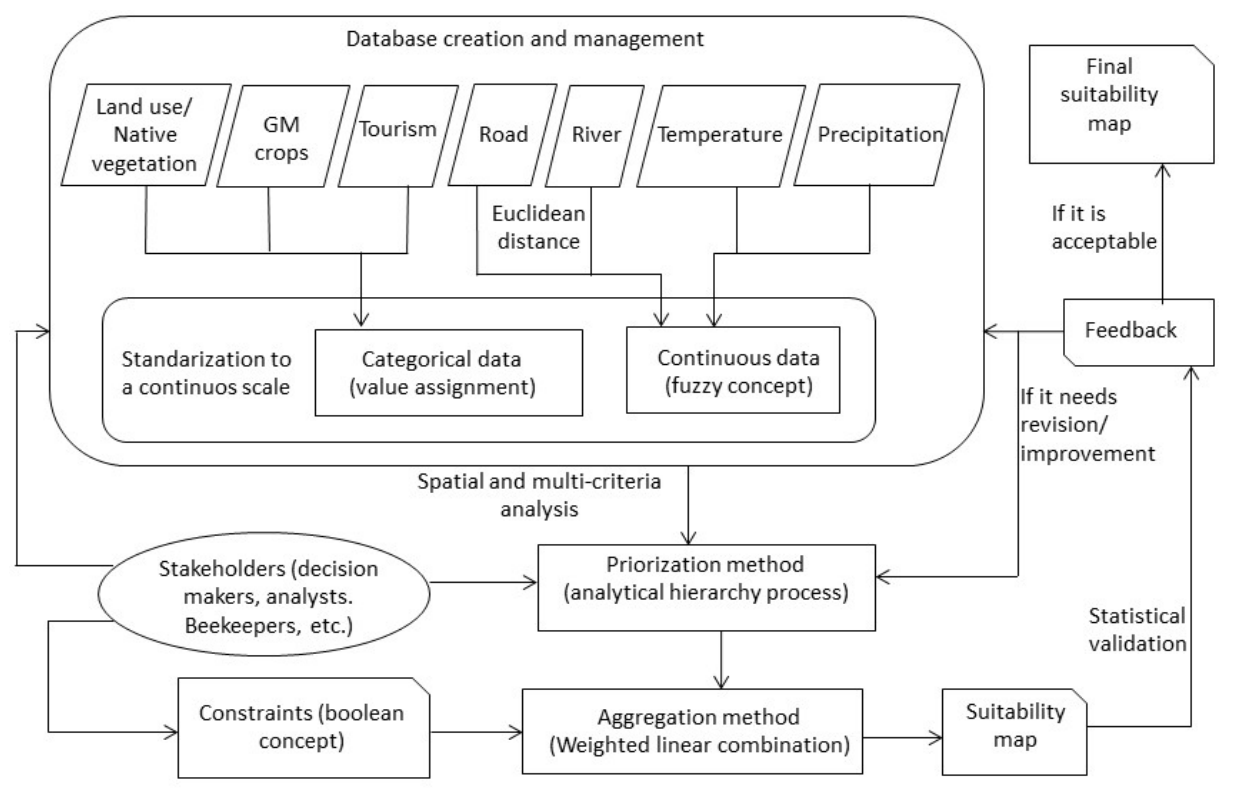

Figure 2. Conceptual model adapted from Estoque and Murayama (2010). 
Table 1: Data and sources

\begin{tabular}{ll}
\hline Data & Sources \\
\hline Catastro del bosque nativo & CIREN and CONAF (2013) \\
Sistema Nacional de Áreas Silvestres Protegidas del Estado & Regional Government \\
(SNASPE), Prioritary tourism areas and road network & Sistema Geográfico de Consulta Apicola Nacional del \\
GM crops & Servicio Agricola y Ganadero. Season: 2012-2013 \\
Annual precipitation and anual mínimum temperature & Hijmans et al. (2005) \\
Rivers and streams & Albers (2012) \\
Analysis 196 honey samples georeferenced & Programa de desarrollo de Biozonas Apícolas para la \\
Survey & valorización de su Cadena de Valor. ID: 30126395-0 \\
\hline
\end{tabular}

cio Agrícola y Ganadero" were used as the factor 'GM crops' with a 5 and 10 kilometer buffer; the Euclidean distance was used for the factors roads and rivers, that is, to determine whether higher suitability is observed as the road or the river becomes closer; and fuzzy membership was used for temperature and precipitation data and consists of a tool that transforms values onto a scale from 0 to 1 .

Restrictions represented areas where beekeeping is not suitable based on land use, protected wilderness areas (Sistema Nacional de Áreas Protegidas del Estado SNASPE) and road net. These raster layers were reclassified from inputs to values of 1 (suitable), and 0 (unsuitable). A threshold based on suitability levels was determined for each layer to extract the most preferred sites (that is, adjacent pixels with high suitability levels), representing potential sites for apitourism development. Thirty-meter cells were used for all the criteria.

One hundred and ninety-six honeys from the region were sampled between 2011 and 2013. The botanical origin was determined by melisopalinological analysis according to the standard NCH 2981.OF2005 (Montenegro et al., 2008).

Prioritizing species is essential for building a layer of native melliferous vegetation, a complex task in beekeeping because there are different scopes and interests. The environments affecting the hive depend on functions developed at specific times, such as maintenance (winter), reproduction (spring-summer) and production (spring-summer, depending on the product). In the case of products, honey production is the most important in the region, and it was the focal objective of this study. The results of beekeeper surveys were adapted and applied to prioritize native melliferous plant species and combined with the frequency and abundance of the plant species in the melisopalinological analyses from honey samples and literature reviews (Montenegro, 2012). The prioritization of native plant species is not proposed to determine which species has better quality or greater honey quantity but only to reduce the number of species to work with for elaboration of the vegetation layer to be included in the model.

A survey was elaborated using methodology described by Geneletti (2008), in which opinion of interested parties was investigated to identify socio-economic and environmental criteria defining the apitouristic suitability of the territory. A preliminary list with workers linked to beekeeping was generated in which they were asked to invite additional people. Thirty-two surveys were made with interested parties belonging to academic institutions, governmental workers and beekeepers. The surveys were made individually and online. Over the course of the investigation, the results of the survey allowed establishment of the criteria and their weights and the identification of the plant species to prioritize, always in comparison to the literature, including the FAO (1987) guidelines. 


\section{Spatial and multi-criteria analysis}

Based on reflection by Barredo (1996) on multicriteria evaluation, the factors are all the aspects determining apitouristic suitability of the study area, either positively or negatively, such as vegetation, GM crops, tourism, roads, precipitation, temperature and rivers. In contrast, the restrictions are the aspects representing a prohibition or unsuitability of the study area for apitourism. The AHP proposed by Saaty (1977) was used for assigning weights to the factors, and as the rule of decision, we used the weighted linear combination (WLC) (Equation 1) with the help of the raster calculator tool:

$$
r_{i}=\sum_{J=1}^{n} w_{j} e_{i j}
$$

where

$r_{i}$ : Land use suitability for the location of an apitouristic project.

$\mathrm{w}_{\mathrm{j}}$ : Weight of criterion $\mathrm{j}$.

$e_{i j}$ : Normalized value of the alternative $i$ in the criterion $\mathrm{j}$.

$\mathrm{n}$ : Number of criteria involved in the research.

The consistency index was used to assess the consistency of the comparison matrix per factor pair, as defined by Mendoza and Macoun (1999), who state that a maximum consistency index of $10 \%$ is acceptable when a large matrix is used with a number of factors greater than or equal to 5 .

\section{Validation}

A generalized linear model (GLM) was used to validate the spatial model. First, a 651-point-net was built, with each point equidistant at $5 \mathrm{~km}$.
The factor values, restrictions and model were then obtained using the tool "extracting multiple values to points". The matrix was arranged by the following group of vectors: the dependent variable is apitouristic suitability (ATS); the seven independent variables (factors) were tourism, temperature, precipitation, roads, vegetation, GM crops and rivers $\left(\mathrm{aX}_{1}+\mathrm{bX}_{2}+\ldots \mathrm{zX}\right)$; and the three independent Bernoulli-type variables (restrictions) were SNASPE, highways and soil use $\left(A^{*} B^{*} \ldots N\right)$. A predictive multiple linear model was elaborated (Equation 2).

$A T S=f(x)=\left(a X_{1}+b X_{2}+\ldots z X_{n}\right) * A * B * \ldots N$ Equation 2

The variables not explaining the ATS in the model were eliminated by statistical methods, and the variables fulfilling homoscedasticity assumptions and residual normality were selected. The following procedure was made for model validation: the ATS for the 169 points of sampled apiaries was estimated; then, they were compared to the ATS measured in the elaborated GIS map. The comparison was carried out by simple linear regressions and the $\mathrm{Chi}^{2}$ independence test, where $\mathrm{Ho}=$ independent models and $\mathrm{Ha}=$ dependent models.

\section{Importance of plant species}

A modified index of importance value (IVI) proposed by Curtis and McIntosh (1951) was estimated and analyzed using the botanical origins of the honeys. Therefore, the dominance of each species was hierarchized. Each honey sample was used as a unit of analysis for the IVI estimation (Equation 3).

$\mathrm{IVI}=\mathrm{DR}+\mathrm{AR}+\mathrm{FR}$

Equation 3

where

$\mathrm{DR}=$ relative dominance, corresponding to the pollen percentage in each sample and estimated as absolute dominance by species divided by absolute dominance of all species. 


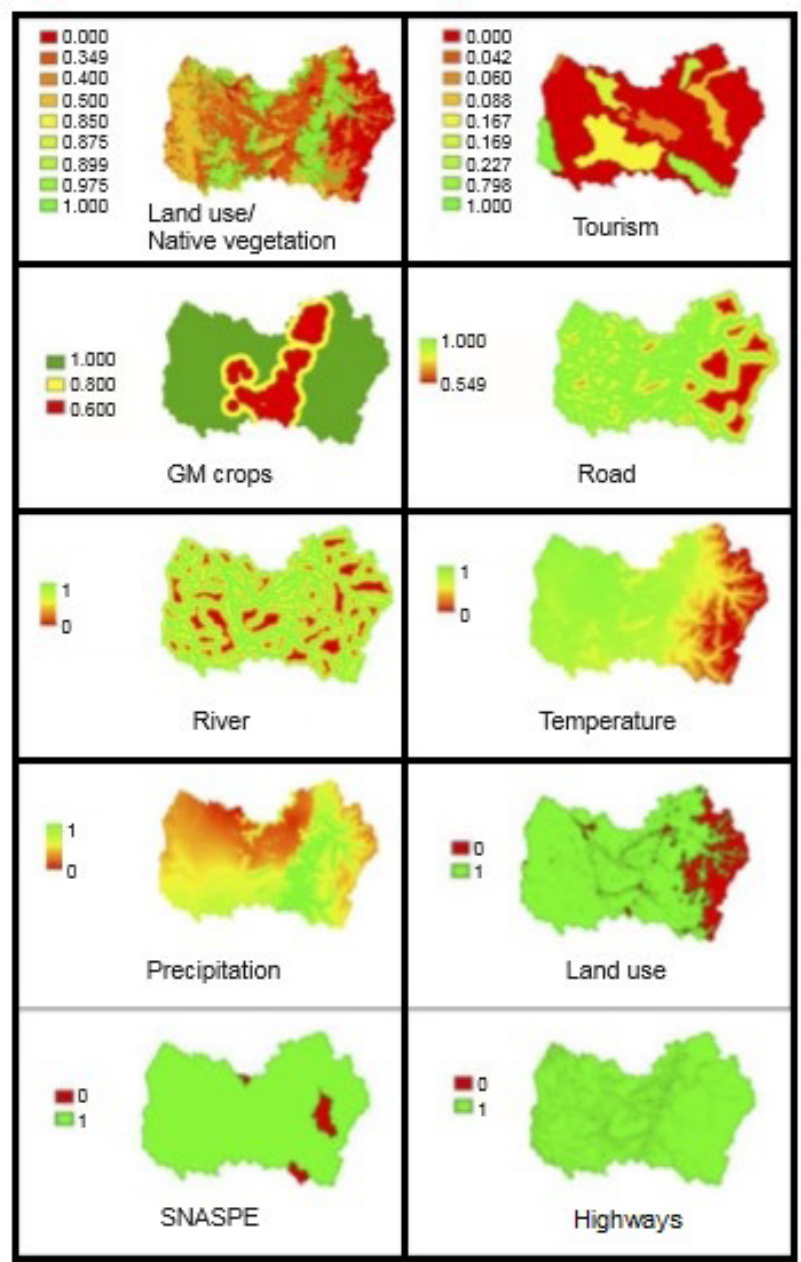

Figure 3. Criteria: factors and restrictions used in the model of apitourism suitability. Factors are: land use/ native vegetation, tourism, GM crops, roads, rivers, temperature and precipitation. Restrictions are: land use, highways and SNASPE (Sistema Nacional de Áreas Silvestres Protegidas del Estado).

$\mathrm{AR}=$ relative abundance, calculated as the species average in each honey sample divided by the total sum of averages.

$\mathrm{FR}=$ relative frequency, calculated as the number of honey samples where the species occurs divided by the sample total.

\section{Results and discussion}

\section{Data base and data management}

Ten criteria were selected ( 7 factors and 3 restrictions) that fulfilled the following requirements
(Figure 3): spatial characteristics, data availability and significant data variability in the study area.

Soil use and the presence of native melliferous species were considered to elaborate the vegetation factor (Table 2). Three soil uses scored as values different from zero; the agricultural lands scored the lowest value. This decision is justified because pesticides are more extensively used in agricultural areas and cause diminished bee reproduction; therefore, the population is restrained. Moreover, the indiscriminate use of agrochemical products is identified as one of the main factors for colony collapse disorder (CCD) (Farooqui, 2013). 
Table 2: Plant species, soil uses and their scores used for creation of a vegetation factor

\begin{tabular}{lc}
\hline Plant species / soil use & Score \\
\hline $\begin{array}{l}\text { Cryptocarya alba, Escallonia pulvurulenta, Kagenckia oblonga, Lithraea caustica, Quillaja saponaria, } \\
\text { Retanilla trinervia, Baccharis linearis }\end{array}$ & 1.00 \\
Colliguaja odorifera, Jubaea chilensis, Salix humboldtiana, Schinus latifolius, Retanilla quinquinervia & 0.95 \\
Aristotelia chilensis, Echinopsis chiloensis, Puya berteroniana, Puya chilensis & 0.90 \\
Acacia caven & 0.80 \\
Natural prairies & 0.70 \\
Agricultural areas & 0.60 \\
\hline
\end{tabular}

Restrictions represent areas where beekeeping is not suitable: areas with active land use (waterbodies, urban areas, industrial areas, barren areas, snow and glaciers); highways net with 50-m-buffer to avoid theft or vandalism; and SNASPE, which includes three areas (i.e., the "Reserva Nacional Rio Los Cipreses", "Parque Nacional Las Palmas de Cocalán" and "Santuario de la Naturaleza Alto Huemul").

Maintaining wild areas protected from beekeeping is relevant because bees may cause negative effects on the ecosystem such as competition with native pollinators for floral resources, and introduction of pathogens and pollination of exotic weeds (Goulson, 2003) and in the case of the honeybee Apis mellifera, for production of honey. As a result several bee species have been introduced to countries far beyond their home range, including A. mellifera, bumblebees (Bombus sp.).

It is important to mention that some criteria useful for determining suitable sites for beekeeping were excluded from this study due to lack of data. First, the criterion on diseases affecting bees is significant, because pathogen-free sites may be prioritized to avoid higher incidence of the mite Varroa destructor, the bacterium Loque americana, and the microsporidia Nosema ceranae, among other diseases; electromagnetic radiation (e.g., from cellphones) can also negatively influence bees by causing an abnormal sound called “worker-piping” (Favre, 2011).

\section{Spatial and multi-criteria analysis}

According to Table 3, the most important criterion was vegetation $(53.49 \%)$, followed by tourism (17\%). The objective was successfully achieved, as we were able to identify sites suitable for beekeeping in tourism-priority zones. In general, the results were in agreement with authors publishing model weights, where vegetation shows the highest weight (Estoque and Murayama, 2010; Sani et al., 2012). However, in the case of climatological data, this study showed a low weighting (4\%), which differs from the value proposed by Sani et al. (2012). The authors estimated beekeeping suitability in the most important floral zone in Iran, and importance was more strongly attributed to climate (approximately 14\%), perhaps because of the drier climate in the country in which ideal ecosystems for bees are scarce.

The index of consistency was an acceptable $6.9 \%$ (Table 3), as the value judgements assigned were coherent and did not require fit or review. Therefore, the index was transformed into an initial sensitivity analysis of the model. However, observations of index changes if a factor is added or eliminated would be of interest to avoid problems such as range changes.

The values of suitability were estimated for the whole O'Higgins Region using the weights from the AHP and WLC in the thematic layers representing factors and constraints on the development of 
Table 3: Paired comparison matrix

\begin{tabular}{lcccccccc}
\hline & Vegetation & Tourism & $\begin{array}{c}\text { Gm } \\
\text { crops }\end{array}$ & Temperature & Precipitation & River & Road & Weight \\
\hline Vegetation & 1 & 5 & 9 & 9 & 9 & 9 & 9 & 0.5349 \\
Tourism & $1 / 5$ & 1 & 3 & 5 & 5 & 2 & 6 & 0.1700 \\
GM crops & $1 / 9$ & $1 / 3$ & 1 & 3 & 3 & $1 / 2$ & 2 & 0.0715 \\
Temperature & $1 / 9$ & $1 / 5$ & $1 / 3$ & 1 & 1 & $1 / 4$ & 3 & 0.0403 \\
Precipitation & $1 / 9$ & $1 / 5$ & $1 / 3$ & 1 & 1 & $1 / 4$ & 3 & 0.0403 \\
River & $1 / 9$ & $1 / 2$ & 2 & 4 & 4 & 1 & 6 & 0.1168 \\
$\begin{array}{l}\text { Road } \\
\text { Consistency }\end{array}$ & $1 / 9$ & $1 / 6$ & $1 / 2$ & $1 / 3$ & $1 / 3$ & $1 / 6$ & 1 & 0.0259 \\
ratio $=6.9 \%$ & & & & & & & & \\
\hline
\end{tabular}

apitouristic activity. The suitability was classified into three ranges: 0 to 0.56 (low suitability); 0.56 to 0.84 (suitable); 0.84 to 0.98 (high suitability) (Figure 4). The cut-off values of these ranges were provided by standard deviation, which was the best method to fit the main objective of the study.

The objective was to select the most appropriate zone, corresponding in this case to the southeastern area of the region (the basin of the Tinguiririca river). This area corresponds to a corridor-shaped environment, shows particularities and uses empowering in its development, unlike other valleys in central Chile. Additionally, the area corresponds to tourism sites such as "Termas del Flaco", "Huellas del Dinosaurio", "Sierras de Bellavista", and "Puente Negro", all of which contribute to the high values of beekeeping suitability due to the presence of native vegetation and beekeeping development. This development is explained by beekeepers working in the sector and providing interesting apitouristic spaces. In this zone, the apitouristic suitability was classified in three ranges: 0 to 0.44 (low suitability); 0.44 to 0.59 (suitable); 0.59 to 0.95 (high suitability) (Figure 5) and the cut-off values of these ranges

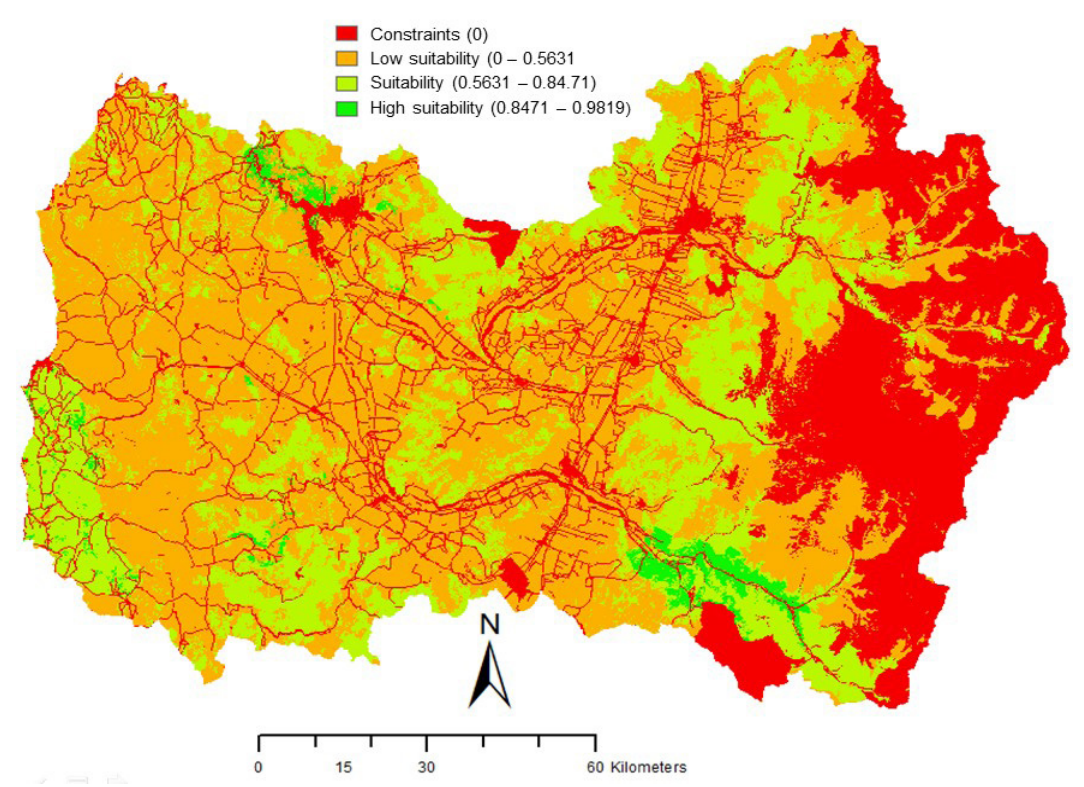

Figure 4. Map of apitourism suitability for the O'Higgins Region. 
were obtained using the quantile method, which was the most adequate for the local scale.

The Rapel Lake and the coastal sector of Pichilemu-Bucalemu represent alternatives to the zone described above (Figure 4). Pichilemu-Bucalemu showed the highest index of tourism priority in the region, especially Las Comillas sector where the family enterprise "Apiturismo Las Comillas" has been established since 2006, promoting and exploiting honey to generate a novel and educational environment. This enterprise displays the process of honey generation, honey syrup and natural pollen from flowers and native trees in the area. Additionally, they sell a wide variety of handicrafts and provide other services such as entertainment for children and a picnic zone. This example of apitourism is well documented by Shiffler (2014) in "Api-Tourism as Added-Value: The Case of La Ruta de la Miel in Chile."

\section{Validation}

In general, the 196 already existing apiaries are located in areas considered adequate for apitourism
(Figure 6) in zones where the model suitability was higher (0.5). Approximately 100 apiaries show a pixel equal or higher than 0.8 , which correspond to highly adequate zones according to the classification proposed by the map of regional suitability (Figure 4). The result is positive and preliminarily validates the model.

The variables GM crops, precipitation and rivers provided insignificant information to the model and were thus eliminated. The model was fit with the variables tourism, temperature, roads and vegetation, with $\mathrm{R}^{2}$ of $99.6 \%$ (SCM: 227.72, g.1.: 4; SCT: 227.952, g.1. 625; value $\mathrm{P}>0.05$ ). Then,

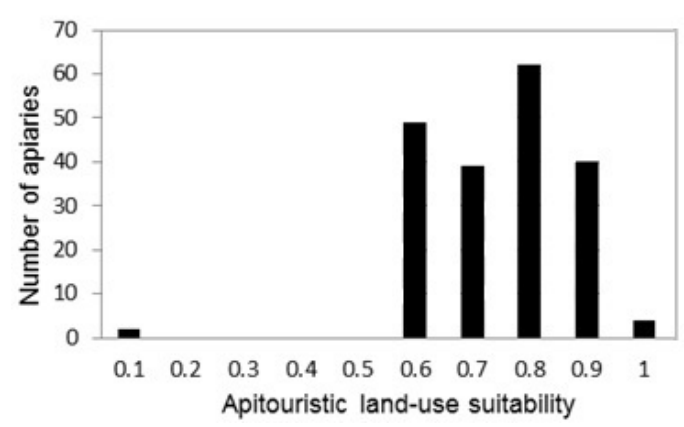

Figure 6. Frequency histogram of 196 geo-referenced and sampled apiaries.

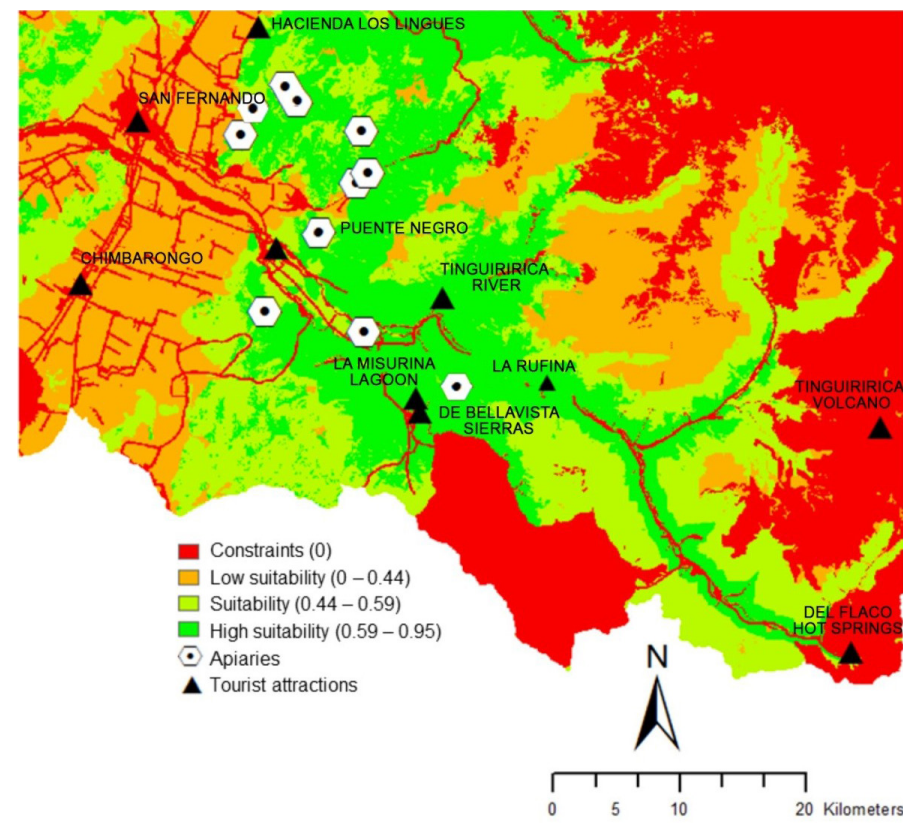

Figure 5. Map of apitouristic suitability for the sector in the Tinguiririca River basin. 
the model (Equation 4) was used to develop the final suitability map.

ATS $=(0.169$ tourism +0.042 temperature $+0.163 \mathrm{r}$ oads +0.627 vegetation $) * A * B * C$ Equation 4

where $\mathrm{A}, \mathrm{B}$, and $\mathrm{C}$ represent the restrictions.

The non-parametric $\mathrm{Chi}^{2}$ test showed the comparison of estimated ATS with the measured ATS results for intimately related vectors (T:7.26, $\mathrm{P}<0.05)$. Additionally, they presented a correlation with a $\mathrm{R}^{2}$ value of $0.97 \%$ (ATS calculated $=0.031+0.939 *$ ATS measured, $\mathrm{P}<0.05, \mathrm{~T}: 63.50$ ) (Figure 7). Therefore, the spatial model is statistically significant, and the mathematical model was a good predictor of the apitouristic suitability for land use.

\section{Importance of plant species}

The melisopalinological analysis showed that of all the 196 sampled honeys, 55 were native unifloral honeys, and 36 were nonnative unifloral honeys. Other honeys presented bifloral characteristics, and 5 were native and 3 mixed. Finally, 34 presented native multifloral features,
60 presented nonnative multifloral features, 1 presented mixed multifloral features, and 2 presented non-floral features (i.e., sugary juice). Half of the honeys produced in the region are virtually native. Furthermore, if the honeys are classified according to their floral composition, then almost half of them are unifloral. This means that there is a huge potential for honeys with replicable chemical and organoleptic features maintained year after year, which is essential for differentiating products. However, bees are selective according to the sugar concentration in nectar and species diversity in flowering, as well as the particular needs for nutrients demanded by the beehive. Bees tend to visit flowers with nectar composed of $15 \%$ sugar (Montenegro et al, 2009).

IVI estimation allowed the prioritization of melliferous species, identifying flowers preferred by bees (Table 4). The most important botanical families are Fabaceae, Asteraceae and Brassicaceae, which is in agreement with results from the literature showing that Fabaceae is one of the most frequently visited families in Argentina (Sala and Suarez, 1985), Brazil (Camargo et al., 2014) and Chile (Montenegro, 2012).
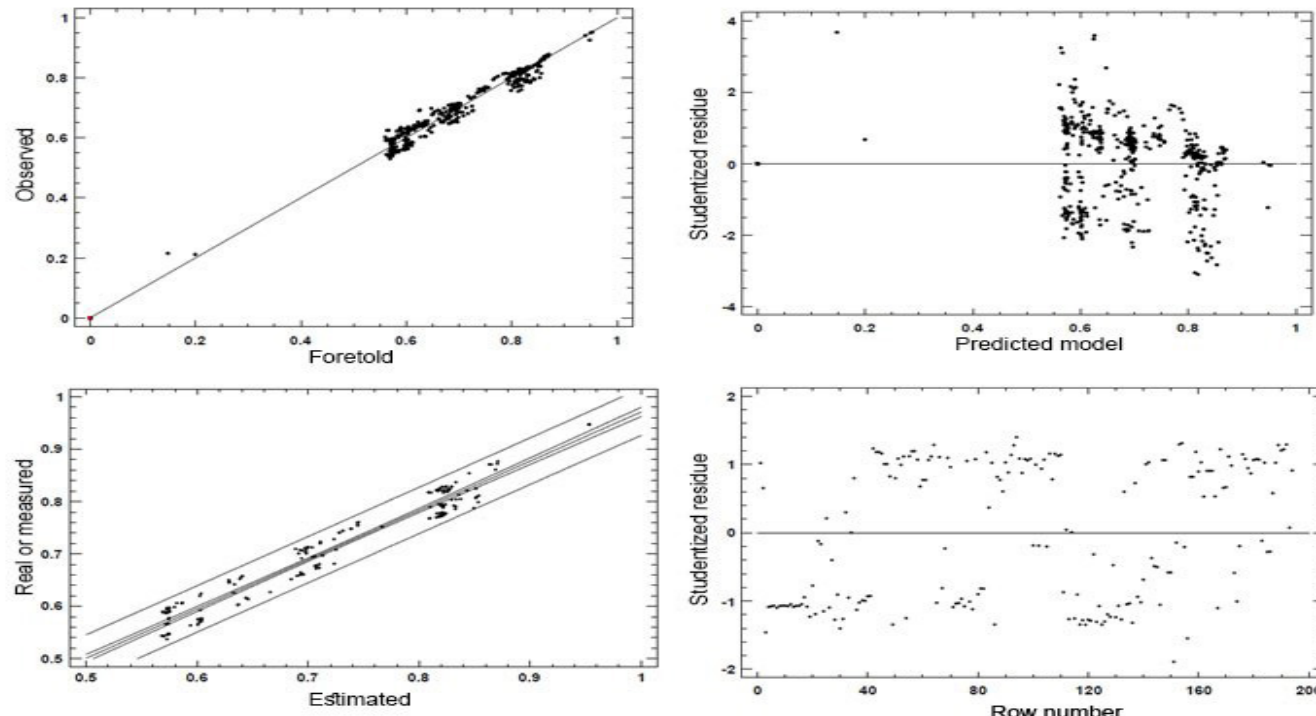

Figure 7. Parameter graphics of the generalized linear model and model validation. 
Table 4: Index of importance value (IVI) for plant species in pollen from honeys in the O'Higgins Region (Chile)

\begin{tabular}{lcll}
\hline Species & IVI & Species & IVI \\
\hline Galega officinalis & 1.3014 & Schinus molle & 0.2577 \\
Quillaja saponaria & 1.1623 & Eschscholzia californica & 0.2482 \\
Medicago sativa & 1.0706 & Calceolaria sp. & 0.2321 \\
Trifolium repens & 0.9796 & Salix humboldtiana & 0.1798 \\
Brassica rapa & 0.9711 & Daucus carota & 0.1724 \\
Luma/ Myrceugenia & 0.8825 & Kageneckia oblonga & 0.1495 \\
Azara sp. & 0.8127 & Maytenus boaria & 0.1346 \\
Retanilla trinervia & 0.7989 & Echinopsis chilensis & 0.1273 \\
$\begin{array}{l}\text { Trevoa quinquinervia } \\
\text { Escallonia }\end{array}$ & 0.5953 & Echium vulgare & 0.1179 \\
pulverulenta & 0.5896 & Crinodendron patagua & 0.1168 \\
Lithraea casutica & 0.5345 & Colliguaja odorifera & 0.1003 \\
Eucalyptus globulus & 0.4361 & Sisymbrium sp. & 0.0954 \\
Taraxacum officinalis & 0.3704 & Rumex acetosella & 0.0939 \\
Melilotus indicus & 0.3478 & Adesmia sp. & 0.0581 \\
Lotus uliginosus & 0.3241 & Raphanus rhapanistrum & 0.0531 \\
Aristotelia chilensis & 0.3096 & Cuscuta chilensis & 0.0506 \\
Rubus ulmifolius & 0.3002 & Euphorbia sp. & 0.0446 \\
Buddleja globosa & 0.2584 & & \\
\hline & & &
\end{tabular}

Galega officinalis was the species with highest index of importance value (Table 4), which is used as source of nectar and pollen by melliferous bees while the species is flowering between September and March. Co-occurrence of exotic species such as G. officinalis, Medicago sativa, Trifolium spp. and Brassica spp. shows that the apiaries are located in agricultural zones. This is in agreement with results by Grimau et al. (2014), who remark on the importance of weeds for honey production in the region. In fact, a relevant percentage of the region under study corresponds to agricultural fields (25\%). Therefore, it is important to develop public policies addressing the relevance of agrosystemic management on sustainable beekeeping development, preserving semi-natural areas adjacent to cultivated lands, and sowing melliferous species along rural roads. The idea is to increase native plant biodiversity and preserve their pollinating agents.
Quillaja saponaria was in second place with and IVI of 1.16. This species is an endemic tree in central Chile with abundant flowering that produces large quantities of nectar (Díaz-Forestier et al., 2009). Melliferous bees collect nectar and pollen from flowers approximately between October and January. Unifloral honey from Quillay is associated with wide zones with slightly modified native forest. Studies show that honeys adopt the features from the plants they are extracted from; the most documented case is Quillay, with beneficial features such as antioxidant, antibacterial and antifungal capacity (Montenegro et al., 2009). Therefore, endemic unifloral honey from Quillay always represents quality honey that is desirable for any beekeeper. Tebo (Retanilla trinervia) corresponded to another important native species, used as a source of nectar at the beginning of beekeeping seasons when beehives are performing early season activities. 
The main conclusions are as follows. GIS and MCDA were shown to be useful tools for mapping apitouristic suitability of the territory where a versatile set of guidelines was included. The development and validation of the map of apitouristic suitability for the O'Higgins Region was successful using the conceptual empirical model. The usual collaboration of experts and the cyclic nature of the model are the strengths utilized to obtain pleasant and acceptable results.

It is necessary to extend the prioritization methodology for plant species in seasonal terms, that is, to include all the species influencing a beekeeping year because some low-commercial-value melliferous species certainly grow during the year and play important roles in beehive maintenance. This could change priorities when food is scarce or the production system becomes expensive when artificial feeding is applied. On the other hand, the index of importance value allowed the identification of plant species effectively visited by bees, information that becomes useful for plans of native reforestation management.

The result of the statistical validation transformed a 7-factor model to a more "parsimonious" model, this is, a simpler 4-factor model explaining the same. Apitourism is an innovative form of tourism that is suitable for the territory under study, and represents a real opportunity for small beekeepers in rural areas of the region in terms of new job positions, support for the development of local infrastructure and promotion of the region. From the research point of view, it is reasonable to say that optimal development of apitourism will also require support from the government and local organizations responsible for rural development.

\section{Resumen}

G. Pantoja, M. Gómez, C. Contreras, L. Grimau, y G. Montenegro. 2017. Determinación de zonas adecuadas para uso apiturístico, mediante evaluación de multicriterios, en sistema de información geográfica: Estudio de caso en la Región O’Higgins, Chile. Cien. Inv. Agr. 44(2): 139-153. La apicultura se ha convertido en una actividad productiva importante, que implica la producción de miel y la polinización de cultivos agrícolas. Vincular la apicultura con el ecoturismo proporciona mayor valor al sector apícola, permitiendo el desarrollo del apiturismo. El análisis de decisión multicriterio (MCDA) es un conjunto de técnicas desarrolladas a través de un Sistema de Información Geográfica (SIG), centrado en la toma de decisiones espaciales, que puede ser utilizado para vincular la apicultura y el turismo en el desarrollo de sitios prioritarios con actividad compartida. Este trabajo se basa en la definición y ponderación de factores utilizados para la evaluación de la idoneidad apiturística en Chile, considerando la opinión de apicultores y profesionales relacionados con el sector. El resultado es un mapa de aptitud apiturística, que incluye: vegetación, turismo, precipitación, temperatura, carreteras, ríos y cultivos genéticamente modificados (cultivos transgénicos) y tres restricciones: uso del suelo, caminos y áreas silvestres protegidas por el Estado. El modelo permitió la localización de sitios donde los recursos y esfuerzos para el desarrollo apiturístico son prioritarios.

Palabras clave: Análisis de aptitud para el uso de la tierra, análisis de decisión multicriterio (MCDA), apicultura, planta melífera, sistema de información geográfica (SIG), turismo. 


\section{References}

Albers, C. 2012. Coberturas SIG para la enseñanza de la Geografía en Chile. Universidad de La Frontera. Temuco.

Amiri, F., A.B.M. Shariff. 2012. Application of geographic information systems in land-use suitability evaluation for beekeeping: A case study of Vahregan watershed (Iran). Afr J Agric Res 7(1):89-97.

Babaie-Kafaky, S., A. Mataji, and N.A. Sani. 2009. Ecological capability assessment for multipleuse in forest areas using GIS-based multiple criteria decision making approach. Am J Environ Sci 5(6):714.

Barredo, J.I. 1996. Sistemas de Información Geográfica y Evaluación Multicriterio en la ordenación del territorio. Rama. Madrid.

Basualdo, M., and E. Bedascarrasbure. 2003. Rol de las abejas en la polinización de cultivos. IDIA XXI. Revista de Información sobre Investigación y Desarrollo Agropecuario del INTA 5:18-22.

Bojórquez-Tapia, L., S. Díaz-Mondragón, and E. Ezcurra. 2001. GIS-based approach for participatory decision making and land suitability assessment. Int. J. Geogr. Inform. Sci. 15:129-151.

Camargo, S.C., R.C. Garcia, A. Feiden, E.S. De Vasconcelos, B.G. Pires, A.M. Hartleben, and D.J. Pereira. 2014. Implementation of a geographic information system (GIS) for the planning of beekeeping in the west region of Paraná. An Acad Bras Cienc 86:955-971.

Cárcamo, C. 2010. Plan de exportación de un conglomerado de cooperativas apícolas en la zona centro-sur del país. Tesis Magister. Facultad de Ciencias Agronómicas, Escuela de Pregrado, Universidad de Chile. Santiago, Chile.

CIREN, CONAF. 2013. Informe técnico final. Proyecto: Monitoreo de cambios, corrección cartográfica y actualización del catastro de bosque nativo en las regiones de Valparaíso, Metropolitana y Libertador Bernardo O'Higgins. 130 pp.

Curtis, J.T., and R.P. McIntosh. 1951. An upland forest continuum in the pariré-forest border region of Wisconsin. Ecology 32:476-496.
Díaz-Forestier, J., M. Gómez, and G. Montenegro. 2009. Nectar volume and floral entomofauna as a tool for the implementation of sustainable apicultural management plans in Quillaja saponaria Mol. Agroforestry Systems 76(1):149-162.

Di Castri, F., and E. Hajek. 1976. Bioclimatología de Chile. Santiago, Chile: Ediciones de la Universidad Católica de Chile. 128 pp.

Estoque, R.C., and R.C.E. Murayama. 2010. Suitability analysis for beekeeping sites in La Union, Philippines, using GIS and multi-criteria evaluation techniques. Res J Appl Sci 5:242-253.

FAO. 1987. Urban forestry: Cities, trees and people. An International Journal of the Forestry and Food Industries 39.

Farooqui, T. 2013. A potential link among biogenic amines-based pesticides, learning and memory, and colony collapse disorder: a unique hypothesis. Neurochem Int 62(1):122-136.

Favre, D. 2011. Mobile phone-induced honeybee worker piping. Apidologie 42(3):270-279.

Geneletti, D. 2008. Incorporating biodiversity assets in spatial planning: Methodological proposal and development of a planning support system. Landsc Urban Plan 84(3-4):252-265.

Glaría, V. 2013. Evaluación exploratoria de sustentabilidad de tres socio-ecosistemas en el matorral y bosque esclerófilo de Chile Central. Polis 34:1-19.

Goulson, D. 2003 Effects of introduced bees on native ecosystems. Annual Review of Ecology, Evolution, and Systematics 34:1-26.

Grimau L., M. Gómez, R. Figueroa, R. Pizarro, G. Núñez, and G. Montenegro. 2014. The importance of weeds as melliferous flora in central Chile. Cien. Inv. Agr. 41(3):21-22.

Hijmans, R.J., S.E. Cameron, J.L. Parra, P.G. Jones, and A. Jarvis. 2005. Very high resolution interpolated climate surfaces for global land areas. Int J Climatol 25(15):1965-1978.

Leão, S., I. Bishop, and D. Evans. 2004. Spatial-temporal model for demand and allocation of waste landfills in growing urban regions. Computers, Environment and Urban Systems 28(4):353-385. Malczewski, J. 2006. GIS-based multicriteria de- 
cision analysis: a survey of the literature. Int J Geogr Inf Sci 20(7):703-726.

Mendoza, G., and P. Macoun. 1999. Guidelines for Apllying Multi-Criteria Analysis to the Assessmnet of Criteria and Indicators. Journal Forest Ecology and Management 207:145-146.

Montenegro, G. 2012. Polen Apícola Chileno: Diferenciación y usos según sus propiedades y origen floral. Santiago, Chile: Ediciones Pontificia Universidad Católica de Chile. Santiago, Chile. $161 \mathrm{pp}$.

Montenegro, G., F. Salas, R.C. Peña, and R. Pizarro. 2009. Antibacterial and antifungic activity of the unifloral honeys of Quillaja saponaria, an endemic Chilean species. International Journal of Experimental Botany 78(562):141-146.

Montenegro, G., M. Gómez, J. Díaz-Forestier, and R. Pizarro. 2008. Aplicación de la Norma Chilena Oficial de denominación de origen botánico de la miel para la caracterización de la producción apícola. Cien. Inv. Agr. 35(2):181-190.

Myers, N., R.A. Mittermeier, C.G. Mittermeier, G.A. da Fonseca, and J. Kent. 2000. Biodiversity hotspots for conservation priorities. Nature 403(6772): 853-858.

Orsi, F., D. Geneletti, and A. Newton. 2010. Towards a common set of criteria and indicators to iden- tify forest restoration priorities: An expert panelbased approach. Ecol. Indic. 11:337-347.

Saaty, T.L. 1977. A scaling method for priorities in hierarchical structures. TL Saaty. Journal of mathematical psychology 15(3):234-281.

Sala, L.A., and C.M. Suarez. 1985. Sobre la posible existencia de indicadores polínicos en mieles argentinas de importacion. An. Asoc. Palinol. Leng. Esp. 2:361-368.

Sánchez, M., and L. Carvacho. 2006. Estimación de evapotranspiración potencial, ETP, a partir de imágenes NOAAAVHRR en la VI Región del Libertador General Bernardo O'Higgins. Revista de Geografía Norte Grande 36:49-60.

Sani, N., S. Kafaky, and T. Pukkala. 2012. Integration of GIS, RS and MCDM for Ecological Land Suitability Assessment in Multiple-use Forestry. Archives Des. 65(6):59-70.

Shiffler, K. 2014. Api-Tourism as Added-Value : The Case of La Ruta de la Miel in Chile. Master of Science in Agroecology. Norwegian University of Life Sciences, Faculty of Veterinary Medicine and Biosciences.

Simon, H. 1960. The New Science of Management Decision. Harper and Row: New York, NY, USA. Šivic, F. 2013. Apitouristic. Bee World 90(3):66-67. 